\title{
Frequent flyer programmes: Is it a relationship, or do the schemes create spurious loyalty?
}

Received (in revised form): 15th September, 2003

\section{Randall Whyte}

has been a lecturer at the Centre for Tourism, Adelaide Institute of TAFE for the past seven years. He lectures in tourism marketing, business planning and global tourism issues. Prior to lecturing, Randall held management positions with airlines, car rental firms and rail systems. He holds a Master of Tourism Management (by coursework) and a Master of Business (by research) and is currently studying for a PhD in domestic airline deregulation in Australia.

\begin{abstract}
This paper is an extract from a comprehensive study of airline frequent flyer programmes in Australia. It was found that the schemes create spurious loyalty and that repeat purchase is not a proxy for customer satisfaction or commitment. Loyalty is a more complex issue and factors such as the conditions and circumstances in the relationship were found to be important. It was concluded that the schemes are not meeting their objectives.
\end{abstract}

\section{INTRODUCTION}

Since the collapse of Ansett Australia in September 2001, the Australian domestic aviation market has undergone a structural change that is now dominated by Qantas (75 per cent market share) and a rapidly growing Virgin Blue that only commenced operations in August 2000. Qantas has operated its frequent flyer programme (FFP) for over a decade following deregulation in 1990, and now has over 4 million members. Virgin Blue is a value-based airline catering more for the leisure traveller and does not operate a frequent flyer scheme. FFPs are designed as a competitive strategy to

Randall Whyte

Lecturer

Adelaide Institute of TAFE, GPO Box 1872, Adelaide SA 5001, Australia.

Tel: +61 882078468 ; Fax: +61 882078422 ; e-mail:

rwhyte@adel.tafe.sa.edu.au build customer loyalty and encourage repeat purchase from the higher yielding and most profitable market segment the business traveller. Other consumers join the schemes through organisations such as credit cards firms, banks, fly-buy schemes and telephone companies. This paper focuses on the corporate traveller and not on the leisure traveller.

The main reasons why airlines operate these bonus programmes are 'to cultivate brand loyalty and repeat business; to deter smaller airlines from entering established markets; and to allow sponsoring airlines to compile the demographic profiles and travel characteristics of their members through sign-up procedures and computerized flight $\log$-ins'. ${ }^{1}$ Deregulation, the lack of customer loyalty, competition and a generally over-supplied market are cited as the forces that have led to the creation of loyalty programmes. ${ }^{2}$

\section{Benefits}

The Qantas programme is similar to many other carriers in that points are awarded according to the kilometres (miles) flown (distance) and the class of 
travel/fare paid. There are three different membership levels above the basic entry level of Bronze: they are Silver, Gold and Platinum. Each membership level has particular privileges - the higher one's status, the more points one can earn. The number of status credits earned on eligible flights is separate from frequent flyer points. Status credits are granted according to cabin class and destination. Service privileges and mileage rewards also extend to alliance partner airlines (Qantas is a member of the One World alliance) and other benefits apply through the use of selected hotels, car rental firms and financial service partners.

Membership is open only to individuals at least two years of age or those purchasing a seat, and membership is not open to companies, partnerships or other similar persons or government departments or agencies. Compared to the USA, the schemes in Australia are relatively generous in that they allow the redemption of miles to an extended family and points may be accumulated up to a maximum of five years before they would expire.

\section{PURPOSE OF THE RESEARCH}

The aim of the study was to examine the concept of loyalty marketing through the application of FFPs in Australia's domestic aviation market. Its purpose was to obtain insights into the attitudes and behaviour of corporate frequent flyers, and to investigate whether airline loyalty schemes are attaining loyalty objectives. More specifically, the objectives were:

- to obtain the airline perspectives of their FFPs;

— to establish a profile of the corporate frequent flyer member;

- to obtain insights into the attitudinal and behavioural characteristics of corporate frequent flyers;
- to investigate whether airline loyalty programmes are attaining loyalty objectives.

Rather than determine hypotheses and set out to prove or disprove them, this approach enabled a broader view of the schemes.

\section{RELATIONSHIP MARKETING/LOYALTY MARKETING}

The concept of relationship marketing first appeared in the literature during the mid-1980s and gained greater debate through the 1990s. As the airline industry was at the forefront in promoting loyalty schemes, they began to attract the attention of researchers. Most writers found problems with the schemes: for example, whether the schemes are a sustainable competitive strategy, ${ }^{3}$ the ethical dimension of the schemes, ${ }^{4}$ while some writers identified issues concerning the members, the airlines and other authorities such as competitor watchdogs. ${ }^{5-7}$

Three distinctively different schools of thought are apparent in the literature concerning the existence of relationship marketing. First there is the 'Finnish-led school' that argues for a new way of conducting business and that relationship marketing is a 'paradigm shift'. ${ }^{8}$ Secondly, there are those who doubt the existence of a new concept but reluctantly accept the presence of loyalty schemes. For example, Gilbert views airline frequent flyer schemes as a 'sophisticated form of sales promotion'. ${ }^{9}$ Thirdly, there are those antagonists who do not accept that marketing requires a new definition and are plainly against the concept of relationship marketing.

Are the terms 'relationship marketing' (RM) and 'loyalty marketing' interchangeable and do they mean the 
same? Those that discuss RM have adopted a theoretical viewpoint, whereas those discussing loyalty tend towards its application and measurement from a management research perspective. From here, the term loyalty marketing is used.

One of the driving forces that lead to loyalty schemes is the growing importance of customer retention. Rather than continually fight for market share, marketers recognised that by concentrating their efforts on those that have the ability to make repeat purchases and be 'lifelong customers', this would reduce the cost of marketing and create a solid base of repeat customers. ${ }^{10}$ Changes in the marketplace, the increase in competition (relative parity and lack of differential advantage, deregulated industries and accessible market information), the rising cost of marketing and the fragmentation of consumer markets have all contributed to the loyalty-marketing concept. ${ }^{11}$

Airlines were able to introduce the schemes because fundamentally they market a 'perishable' product - that is most airlines operate somewhere in the 70 per cent plus year-round load factor, therefore many flights will have spare, unsold seats. Thus, the airlines regard it as a marginal extra cost to operate FFPs and provide an incentive for repurchase. The rewards (free flights) can be used for further business travel, although this creates the problem of seat availability on peak days/times; therefore, many members prefer to use their accrued points for holiday travel including family members. There have, however, been many reported problems with the schemes such as closeout periods, lengthy advance booking notice, limited space and other restrictions. ${ }^{12-14}$

Some authors have criticised the schemes as a form of commercial bribery. Arnesen and Fleenor were strongly critical of the schemes and their ethical dimensions and ask why it is that one group of employees who are required to fly are rewarded and another group who are not required to fly are unrewarded. ${ }^{15}$ These authors also pointed out the abuse of the schemes. For example, a frequent flyer plans his/her itinerary in such a way as to travel on the airline they hold membership of even if the routing takes longer or where an airfare could be obtained more cheaply on another airline.

These situations raise doubts about whether the schemes create 'sustained loyalty', ie a feeling of emotional attachment, a bond, trust and commitment. The schemes create an illusion of loyalty through continued repurchase yet there are other factors affecting the relationship. This includes how the relationship was formed - for example, an employee transferring to a new employer may be forced to join a different airline scheme because of the new employer's corporate purchasing arrangements. An individual's bank, credit card firm or telephone company may have a preferential arrangement with one airline that gives the consumer little choice. Situations arise where one continues to support a particular airline merely to build up sufficient points to earn a free flight. In other situations, and more so in Australia, only one carrier may serve a particular destination. Other situations arise such as a travel firm earning override commissions to direct its business to a preferred airline. A medium- to large-sized firm is likely to have a corporate purchasing policy where a preferred arrangement with an airline and/or travel company is preferred. In these situations it is wrong to assume that repeat purchase and customer satisfaction is a proxy for loyalty because it is the circumstances and conditions that affect the relationship. ${ }^{15}$ For example, continued shopping at one's convenience 
store may be merely because of the store's trading hours or easy walking distance from home. The convenience aspect affects buying decisions in a positive way, but there is no intention of a relationship between the shopper and the convenience store. Thus, it is not a relationship at all. The term 'loyalty' is often used loosely and conjures up various notions of 'affection', 'fidelity' or 'commitment'. ${ }^{17}$

Dick and Basu developed a framework to measure loyalty according to behavioural attitudes and determined there are four categories of loyalty - no loyalty, spurious loyalty, latent loyalty and sustainable loyalty. ${ }^{18}$ No loyalty can mean the member is open to other offers from competitors and belongs to the scheme to collect the rewards. There is little or no emotional bond or feeling of commitment to the firm. Spurious loyalty has the appearance of loyalty and the member continues to travel with the airline because they are 'locked in' for some reason. It is not a two-way relationship because while the member continues to repurchase the firm's product, there is no feeling of loyalty or commitment by the individual. Latent loyalty suggests a form of hidden loyalty that lies within a member's relationship with a particular airline. For example, Qantas is known as a very safe and reliable airline; it has greater frequencies and flies to more destinations than its domestic competitor and has an FFP scheme that rewards repurchase; or the member may be accumulating points for a family holiday and continues to support the airline. Sustained loyalty is the most ideal form that means total commitment to the product/service - a strong feeling of attachment, emotional bond and trust. In sustained loyalty, the individual desires a two-way relationship. For this study, these categories were used in this research.

\section{METHODOLOGY}

Primary research for this study was conducted by acquiring a commercial database compiled by a national hotel group from an extensive telemarketing exercise to identify those executives in Australia classified as 'frequent business travellers'. This approach was necessary because Qantas would not permit access to their members or permit interviews to take place in their airport lounges. It was decided to limit the framework to South Australians to keep the study within a manageable proportion and limit the cost of mail-out surveys. The database had 444 names in South Australia and every second name was chosen to arrive at an expected minimum return of 100 surveys.

The database used proved to be a reliable sampling unit with only a few respondents from the survey eliminated because they were not current frequent flyer members. The mail survey enabled more questions to be included and was more likely to eliminate less than truthful answers to questions concerning loyalty had surveys been conducted within airline confines.

A total of 222 surveys were mailed out that yielded an excellent response rate of 59.5 per cent (132 usable surveys).

Non-respondents were not followed up because of cost and timing.

\section{Questionnaire design}

A five-page structured questionnaire was sent out with an accompanying letter briefly introducing the purpose of the study. For ease of convenience and in processing the data, the majority of questions were of a closed type with multiple choice selections, scaling and ranking questions including the use of an itemised-ratings scale. The popular semantic-differential technique was used to measure attitudes of corporate frequent flyers. 
The first group of questions sought information from respondents concerning airline membership to an FFP, duration, category (tier level) and whether this had changed since becoming a member and reasons for the change. The final part of the questionnaire contained questions relating to travel characteristics - the number of business trips (domestic and international) normally undertaken in a year, the class of travel booked, and the usual sociodemographic questions.

Respondents were asked how they thought their company purchased air travel; whether their company (1) had a policy concerning the redemption of points and (2) whether the individual could use accrued points for pleasure travel.

Attitudinal characteristics were obtained from several questions relating to trust and commitment, keeping track of flights and points accrued, whether they thought their business was highly valued, problems experienced redeeming rewards and what effect this had on their attitude towards the airline. Service attributes taking precedence over rewards were tentatively explored.

To test 'commitment', respondents were asked their feelings towards the airlines. Words such as attachment, affection, emotional bond and trust were used to convey the meaning of 'commitment'. Again, a scale was used that allowed respondents to tick a box for each airline that showed 'highly committed' (meaning complete loyalty), 'quite committed' (mostly loyal), 'not very committed' (low loyalty) and 'not at all committed' (no loyalty). These loyalty dimensions were those referred to earlier according to Dick and Basu.

\section{Processing and analysing the data}

The SPSS (Statistical Package for Social Sciences) software package was used to code and enter the raw data that enabled the generation of a frequency table for each variable. Next, from the two or more variables many cross-tabulations received simultaneous treatment. Cross-tabulation is one of the more useful devices for studying the relationships among and between variables since the results are easily communicated but it cannot establish causality.

'Commitment' was set as a dependent variable to cross-tabulate responses to independent variables such as duration of membership, number of business trips, class of travel, age and gender.

'Commitment' was again used as a dependent variable to determine behavioural attitudes and loyalty to one's current airline.

\section{LIMITATIONS}

There were of course several limitations to this research. These include the facts that:

- subjects in the sample were only drawn from the state of South Australia;

- the subjects in the sample were obtained from a commercially acquired database of frequent business travellers;

- the sample was small - 132 surveys from a mail-out of 230 questionnaires;

- the sample represents only Qantas members, as they are the only airline in Australia with an FFP;

- as a satisfactory response rate was received to the mail survey, non-responses were not followed up.

Other limiting factors were time and cost.

\section{FINDINGS}

Space limits the amount of data that can be shown; therefore only the more interesting results are shown. 
Obtaining airline perspectives (Objective 1) proved to be difficult because the airlines are only prepared to discuss the schemes in more general terms rather than the impact of loyalty programmes on revenue, market share, profit and the costs associated in operating the schemes. Most of the Qantas responses were fairly predictable.

\section{Corporate frequent flyer profile}

The profile of the typical corporate frequent flyer was found to be predominantly male (75 per cent), middle-aged and either a senior company executive, manager or professionally employed. The sample also found the following behavioural characteristics:

- up until the time of the Ansett collapse, a high percentage (42 per cent) of corporate frequent flyers held dual membership;

- the majority of members have been in the schemes for more than five years;

- for a majority of members, their membership category has changed since joining the schemes - at least once, and mostly because of an increase in the amount of annual travel;

- corporate frequent flyers predominantly book full economy class travel for domestic travel; for international travel, there is a noticeable shift up to business class;

- quantifying the typical corporate frequent traveller by the number of trips shows no one dominant pattern; this study found that 22 per cent take more than 20 trips per annum;

- the individual member's choice of airline has shown that almost half the respondents are governed by a corporate policy;

- an overwhelming majority of members can use the accrued points for their own use. Only a small percentage of respondents' replies indicated their company has a policy on how the points had to be used. This includes government employees who may only use accumulated points for official travel.

These findings have provided a more updated profile and attributes of a corporate frequent flyer than those reported in an earlier study by Browne et al. ${ }^{19}$ This includes duration of membership and tier level, reasons for change in membership, number of trips into four thresholds and industry classification. Answers were also obtained such as how travel is purchased, whether the member's company has a policy governing the use of points and whether the employee (member) can use accumulated points for pleasure travel for himself/herself and other family members.

\section{Relationship commitment}

Only 7 per cent of respondents stated that they were 'highly committed' (completely loyal) to the airline (Figure 1). A further 45 per cent were 'quite committed' (mostly loyal) meaning that just over half the respondents (52 per cent) feel some attachment, bond or affection to the airline. A total of 29 per cent, however, were not very committed of which 6 per cent were 'not at all committed'. The remaining 19 per cent did not have an opinion or were unstated concerning their level of commitment.

Table 1 shows the results of analysing three variables to test loyalty attitudes according to gender, tier level and duration of membership. Females are slightly more loyal than males (57 per cent versus 50 per cent). Loyalty increases among platinum level members possibly attributable to greater benefits. 


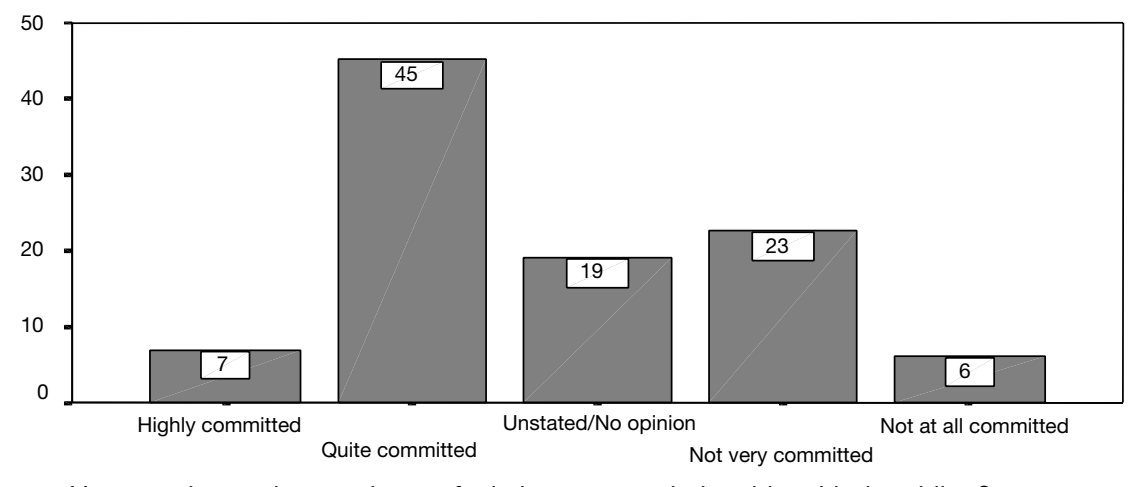

How much attachment do you feel about your relationship with the airline?

Figure 1 Commitment/Loyalty to airline - All membership categories

Table 1: Loyalty according to gender, tier level and duration of membership

\begin{tabular}{lcccc}
\hline & $\begin{array}{l}\text { Percentage } \\
\text { members }\end{array}$ & $\begin{array}{l}\text { Completely or } \\
\text { mostly loyal }\end{array}$ & $\begin{array}{l}\text { Low or no } \\
\text { loyalty }\end{array}$ & $\begin{array}{l}\text { Unstated/ } \\
\text { no opinion }\end{array}$ \\
\hline $\begin{array}{l}\text { Gender mix: } \\
\text { Males }\end{array}$ & 75.0 & 50.0 & 28.0 & 22.0 \\
Females & 25.0 & 57.0 & 25.0 & 18.0 \\
& 100.0 & & & \\
Membership level: & & & & \\
Basic (Bronze) & 42.0 & 39.0 & 35.0 & 26.0 \\
Silver & 34.0 & 48.0 & 30.0 & 21.0 \\
Gold & 10.0 & 58.0 & 21.0 & 15.0 \\
Platinum & 14.0 & 69.0 & 16.0 & \\
& 100.0 & & & 32.0 \\
Duration of membership: & & & & 26.0 \\
Less than 1 year & 6.0 & 44.0 & 24.0 & 21.0 \\
Between 1-2 years & 8.0 & 47.0 & 27.0 & 20.0 \\
Between 2-3 years & 11.0 & 49.0 & 30.0 & \\
Between 3-4 years & 17.0 & 49.0 & 31.0 & \\
Over 5 years & 58.0 & 48.0 & 33.0 & \\
& 100.0 & & & \\
\hline
\end{tabular}

Loyalty diminishes the longer the member has been in the scheme.

\section{Business valued}

Less than half the respondents were in agreement with a statement concerning their business being highly valued and recognised by the special attention given by the airline. Some respondents added a comment such as 'Qantas have got me captive', 'only one airline offers points', and 'they don't have to try very hard' (Figure 2).
Members were asked to rank their opinion using a five-point Likert scale to determine members' satisfaction with the tracking and recording of flights to test 'trust'. These results are shown in Figure 3.

\section{Benefits from membership (other than 'free flights')}

Other than 'free flights', 25 other benefits were given - some with a similar meaning. These were analysed and then clustered into eight key benefits 


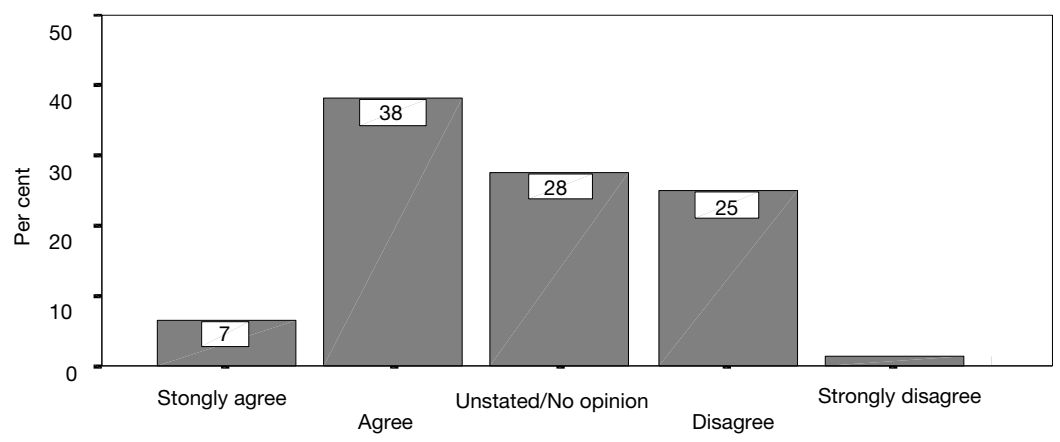

I feel that my business is highly valued and is recognised

Figure 2 Business valued and recognised

Table 2: Business valued and number of trips (Statement: I feel that my business is highly valued and recognised by the special attention given by the airline)

\begin{tabular}{llcr}
\hline Number of trips & Strongly agree/agree & Disagree/strongly disagree & Unstated/no opinion \\
\hline Fewer than 5 & $19(38 \%)$ & $13(26 \%)$ & $37(36 \%)$ \\
Between $5-9$ & $23(34 \%)$ & $27(36 \%)$ & $26(30 \%)$ \\
Between 10-19 & $35(39 \%)$ & $40(37 \%)$ & $21(24 \%)$ \\
More than 20 & $23(42 \%)$ & $20(36 \%)$ & $16(22 \%)$ \\
Totals & 100 & 100 & 100 \\
\hline
\end{tabular}

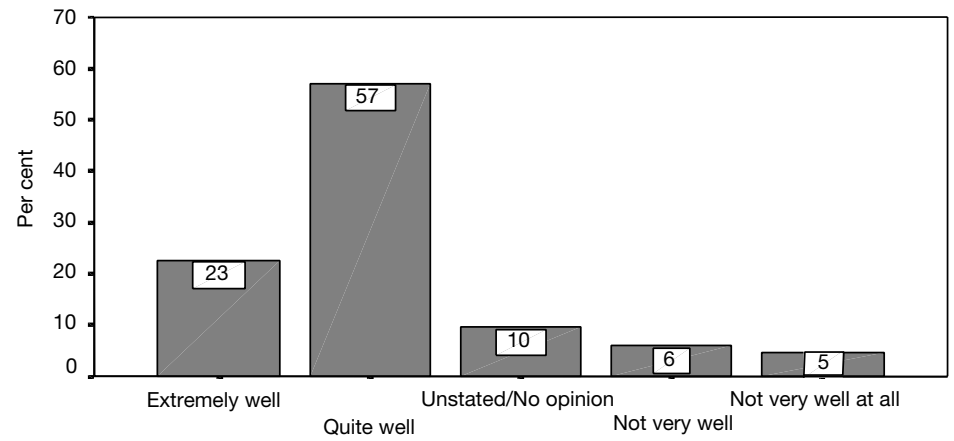

Figure 3 Trust of airline to track flights/points

Table 3: Key benefits

\begin{tabular}{ll} 
Lounge - incl. services in lounges and 'Clubs' & 1 \\
Preferred seating & 2 \\
Priority check-in & 3 \\
Occasional upgrades incl. certificates & 4 \\
Priority baggage & 5 \\
Increased baggage allowance & 6 \\
Partner benefits (alliances/hotels/car rentals) & 7 \\
Booking service & 8 \\
\hline
\end{tabular}




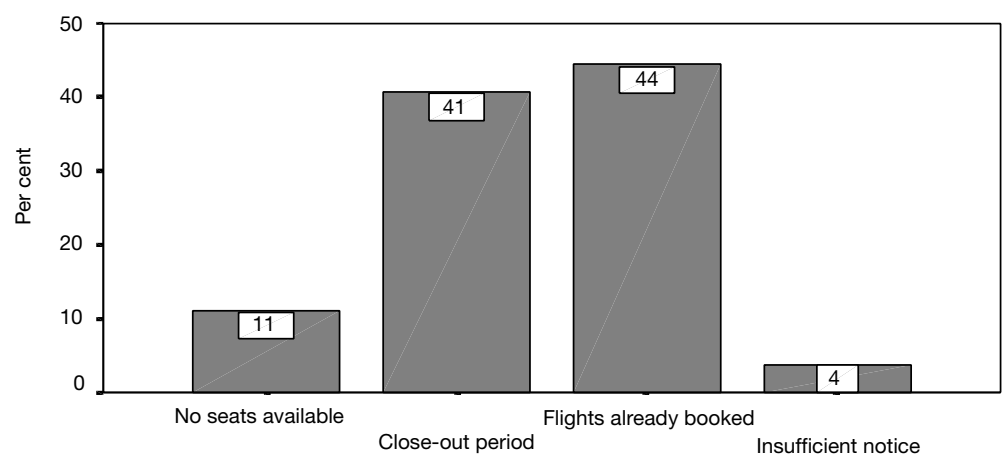

Figure 4 Reasons given by airlines for members unable to redeem points

Table 4: Commitment to airline/effect of company policy (Question: How much attachment do you feel about your relationship with the airline?)

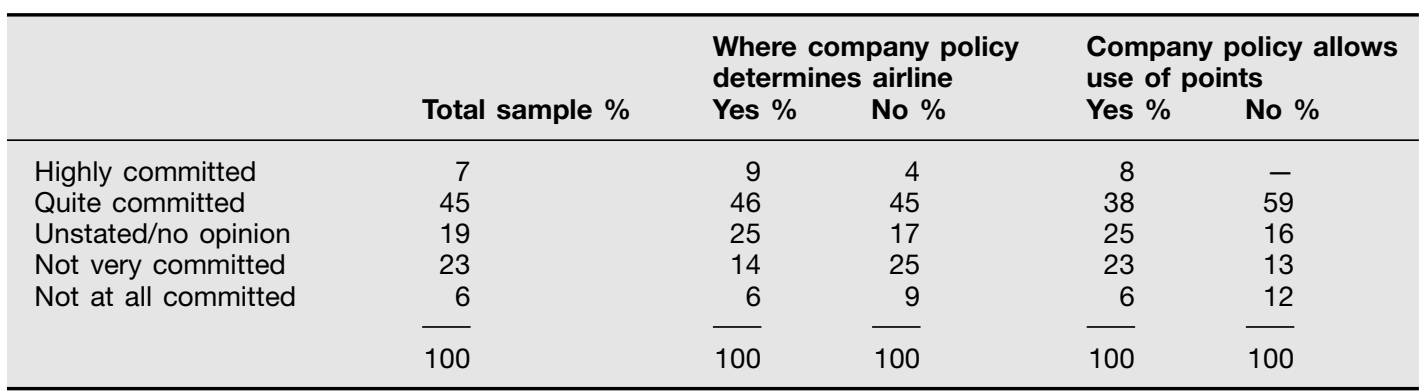

and ranked according to the number of mentions. The results are as shown in Table 3.

\section{Redeeming rewards}

Figure 4 shows the problems encountered by members in redeeming their rewards. The main problem stated was 'no seats available' (88 per cent), however, this response could also mean a close-out, or there is a restricted number of 'free' seats available to FFP members. When asked if the airline gave a reason, 44 per cent of respondents stated 'flight already booked' and 41 per cent stated 'close-out period/peak season'. Respondents were then asked about the recurrence of this problem that showed 'frequently' (28 per cent), 'sometimes' (69 per cent), and 'not at all' only 3 per cent.

Table 4 shows the results of 'Commitment' as the criterion (dependent variable) cross-tabulated with the effect of company policy determining the airline and the company policy concerning the use of points for pleasure travel.

\section{Tied to the rewards versus the company's products/services}

This study showed that 28 per cent of Qantas members feel more tied to the rewards than any feeling of attachment or bond to their airline. A further 25 per cent were 'unstated'. This finding is consistent with the level of 'uncommitted' members and those who feel their business is not valued by the airline. 


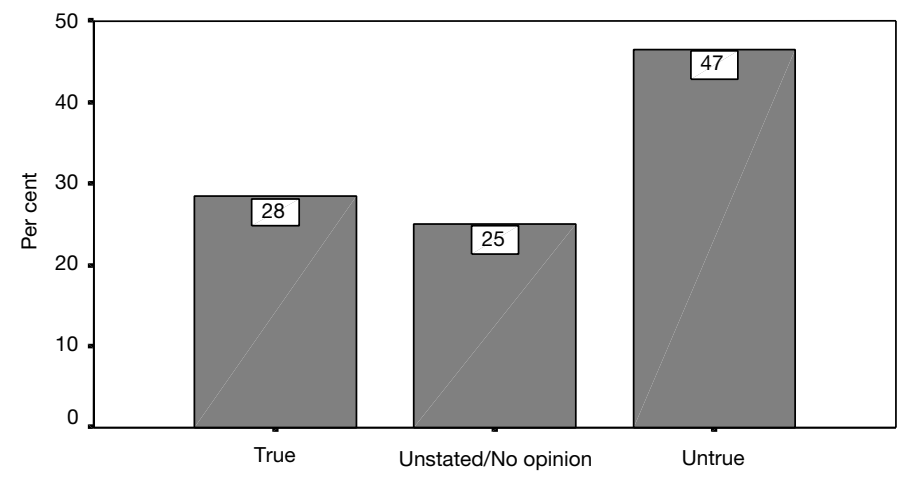

Are you tied to rewards more than products or services?

Figure 5 More tied to rewards than loyalty to airline

Table 5: Service attributes compared to importance of rewards

\begin{tabular}{llll}
\hline & & Neither important & \\
& Important \% & or unimportant \% & Unimportant \% \\
\hline Short-haul flights & 64 & 25 & 11 \\
Medium-haul flights & 76 & 19 & 5 \\
Long-haul flights & 81 & 15 & 4 \\
\hline
\end{tabular}

\section{Service attributes compared to importance of rewards}

Service attributes was only briefly explored to test whether members would be willing to forego points but retain key service aspects. Table 5 shows that members rated service attributes to be more important for long-haul journeys (Sydney/Perth - 4.5 hours) rather than earning points. Respondents to this question mentioned the lack of legroom in economy class.

\section{DISCUSSION}

The corporate profile obtained from the study has provided some useful insights into membership characteristics that might prove useful to other researchers investigating the schemes. A disappointment was the lack of cooperation and reluctance on the part of the airlines to discuss the schemes with private researchers. It was stressed during the initial approach that the researcher was focusing on relationship issues and would avoid commercially sensitive information.

The major finding from the study is that only a small percentage ( 7 per cent) of respondents stated they were 'highly committed' (completely loyal) with a further 45 per cent stating they were 'mostly committed' (mostly loyal) to the airline. More significantly, 23 per cent of respondents were 'not very committed' (low loyalty) and a further 6 per cent were 'not at all committed'. Loyalty is low at both the basic membership level (33 per cent) and as well as with longer duration members. Furthermore, a sizeable percentage ( 28 per cent) of members regard the 'rewards' more highly than any feeling of commitment to the airline, and another 25 per cent were unsure or uncertain. 


\section{Effect of corporate policies}

This area was only tentatively explored; it is evident, however, that company policy governing an individual's airline choice is quite widespread. The issue of loyalty becomes more complex due to the 'relationship triangle' formed between the individual member, the airline and the employer. Airline choice may be determined by corporate purchasing managers to a larger extent than realised.

\section{Switching behaviour}

This study showed that despite problems redeeming points (flights) only a small number ( 8 per cent) decided to switch airlines. This is attributable to the limited choice of domestic airlines in Australia - one of which is a value-based airline and does not operate an FFP (Virgin Blue). Secondly, there is the problem of a 'switch cost'. Members may be unwilling to sacrifice points earned to change airlines. A member may be supporting the airline merely to build sufficient points to earn a free flight. This may result in some tolerance towards a particular airline despite the low level of affection towards the brand.

\section{Implications for loyalty marketing}

The notion of loyalty marketing suggests complete loyalty, however this study has found that there is a high level of disaffection (low loyalty) with members. Loyalty needs to be understood from the conditions and circumstances that prevail before and during the relationship. These conditions and circumstances can mean that some members may not even wish to establish a relationship, or it is one-sided. Secondly, the effect of corporate policy on buying air travel and how it affects the airline/individual member relationship are other areas that are not perhaps widely understood. Thirdly, there are those members who are in the schemes in pursuit of points to earn a free flight the choice of carrier is secondary. Finally, there are those members who display polygamous behaviour. Forty-two per cent of this sample had also belonged to the former Ansett programme. This finding is similar to other studies conducted in the USA and Europe where a member may belong to two or more schemes to retain flexibility or they do not wish to be tied to just one airline. Destination is also a factor as one airline may not suit the individual's travel plans. These are all important conceptual issues for loyalty marketing.

\section{FURTHER RESEARCH}

There are several areas for future research. This includes the corporate environment where more in-depth investigation to obtain a greater understanding of corporate policies and attitudes concerning preferred airline, and policies regarding the use of the rewards, would be useful. More research is needed into investigating members' propensity to switch airlines or stay with their current airline according to service and fare levels, or to switch to an airline that does not offer rewards. Virgin Blue's advertising has now begun to focus on business travellers as well as promoting fares, therefore this area becomes of greater interest due to the presence of a value-based airline now firmly established in Australia's skies.

Although this study suggests that most members place service attributes above the importance of the rewards, more work needs to be done in this area. This study has identified that the importance of service attributes is perceived differently between short-haul, medium-haul, and long-haul passengers. 


\section{CONCLUSIONS}

This study has found that while the airlines are applying loyalty marketing, there are limitations and problems with it. The answers to questions concerning attitudes and behaviour leave little doubt that the schemes create spurious loyalty and are a form of commercial bribery. The schemes encourage repeat purchase because of the reward system - but it is wrong to assume that repeat purchase is a measure of customer loyalty. The member-airline relationship is a far broader concept and other factors need to be taken into consideration. Problems for the airlines include the rapid build-up of unredeemed points (a contingent liability) and the costs of administering and marketing the schemes (including sophisticated IT applications) - yet no airline wants to be the first to withdraw such schemes. The schemes may, at best, influence a member's choice of airline but as a relationship building strategy they are potentially fragile. There is a risk that the airlines could abandon them given the parlous financial state of the industry. Whether these schemes are sustainable in the long term will have to be seen.

\section{References}

1 Browne, W., Toh, R. and Hu, M. (1995)

'Frequent-flier programs: The Australian experience',

Transportation Journal, Vol. 35, No. 2, pp. 35-44.
2 Aijo, T. (1996) 'The theoretical and philosophical underpinnings of relationship marketing', European Journal of Marketing, Vol. 30, No. 2, pp. 8-18.

3 Kearney, T. (1989) 'A failure in competitive strategy, with lessons for management', Journal of Services Marketing, Vol. 3, No. 4, pp. 49-59.

4 Arnesen, D. and Fleenor, C. (1997) 'The ethical dimensions of airline frequent flier programs', Business Horizons, Vol. 40, No. 1, pp. 47-56.

5 Beaver, A. (1996) 'Frequent flyer programs: The beginning of the end?', Tourism Economics, Vol. 2, No. 1, pp. 43-60.

6 Gilbert, D. (1996) 'Relationship marketing and airline loyalty schemes', Tourism Management, Vol. 17, No. 8, pp. 575-582.

7 Palmer, A. and Mayer, R. (1996) 'Relationship marketing: A new paradigm for the travel and tourism sector', Journal of Vacation Marketing, Vol. 2, No. 4, pp. 326-333.

8 Grönroos, C. (1994) 'From marketing mix to relationship marketing: Toward a paradigm shift in marketing', Management Decision, Vol. 21, No. 2, pp. 4-20.

9 Gilbert (1996) op. cit.

10 Bateson, J. (1995) 'Managing services marketing', 3rd edn, Dryden Press, Orlando.

11 Ibid.

12 Beaver (1996) op. cit.

13 Gilbert (1996) op. cit

14 Palmer and Mayer (1996) op. cit.

15 Arnesen and Fleenor (1997) op. cit

16 O’Malley, L. (1998) 'Can loyalty schemes really build loyalty?', Marketing Intelligence \& Planning, Vol. 16, No. 1, pp. 47-55.

17 McGoldrick, P. J. and Andre, E. (1997) 'Consumer misbehaviour: Promiscuity or loyalty in grocery shopping', Journal of Retailing and Consumer Services, Vol. 4, No. 2, pp. 73-81.

18 Dick, A. S. and Basu, K. (1994) 'Customer loyalty: Toward an integrated conceptual framework', Journal of the Academy of Marketing Science, Vol. 22, No. 2, pp. 99-114.

19 Browne, Toh and Hu (1995) op. cit. 